\title{
Evaluation of Good Dairy Farming Practice Method on Dairy Farming in Subang District, West Java, Indonesia
}

\author{
Firman A, Marina S, Hermawan, Paturachman S, Linda H, Anita F \\ Faculty of Animal Husbandry, Padjadjaran University \\ Jl. Raya Bandung Sumedang km. 21, Jatinangor 45363, Sumedang, West Java, Indonesia \\ ahmadpedum@yahoo.com
}

\begin{abstract}
The majority of dairy farms in Indonesia are smallholder producers. The development of dairy farm increases level of income, especially smallholders. Subang District is territory development for dairy farm in West Java. The farm has been set up since 2000 and got training assessment from PT. Danone in 2009. To evaluate the application of the training, this research used Good Dairy Farming Practice (GDFP) model and seven aspects are evaluated. Research results shows that milking hygiene, reproduction, and animal welfare are good implementation. Meanwhile, social economic management aspect is not priority in the dairy farmers. The aspect has similar value with animal health, nutrition, and environment. Therefore, intervention programs that should be trained in Subang District should focus on four aspects: animal health, nutrition, environment, and social economic management.
\end{abstract}

Key Words: Dairy, Smallholders, Good Dairy Farming Practice

\section{INTRODUCTION}

In Indonesia, dairy industry has been built in vertical integration because fresh milk needs quick treatment as anticipation before it becomes expired. Milk is sent to cooperatives, then distributed directly to milk processors. Smallholder producers are pivotal players in dairy farming, meanwhile cooperatives coordinate farmers, not only in milk collection and distribution, but also in many tasks to facilitate farmers such as animal health and artificial insemination services, soft credit loan; feed supply; milk processors, and in determining milk price. On the other hand, milk processors that operate in Indonesia have absorbed approximately 90\% of fresh milk production. These firms have a good bargaining position to determine milk price using their standard.

West Java Province is one of dairy center areas in Indonesia. Based on the number of dairy population and milk production, it takes place on the second position after East Java Province, yet its dairy productivity is the most excellent. Approximately $80 \%$ of the milk producers are smallholder producers, where they have only 2-3 cows per farmer. According to dairy cattle cooperatives (Gabungan Koperasi Susu Indonesia, GKSI), West Java Province has 16,615 dairy farmers, 22 cooperatives, and five milk industry processors which have capacity to accomodate $80-90 \%$ fresh milk from cooperatives.

Dairy farm requires specific condition in its location to set the farm, such as agroecology and environment $\left(19-21^{\circ} \mathrm{C}\right)$. Therefore, only several areas can be set as dairy farm, including some of sub districts in Subang District. The development of dairy farm in Subang has been started since 2000. The development areas for dairy are located in Sagalaherang, Ciater, Tanjungsiang, and Jalancagak. The number of farmers who keep dairy as their main source of income is not as many as those in Lembang. There are 12 farmer groups or 264 smallholders noted as member of North Bandung City dairy cattle farmer cooperatives named as Koperasi Peternak Susu Bandung Utara (KPSBU) (Dinas Peternakan Subang 2014). Almost 95\% of milk production is distributed by KPSBU. The 
problems occur when handling disease, feeding, breeding, and financial aspects. Those problems can be threatened on the milk production.

In 2009, PT Danone gave a training to improve the way of their keeping the dairy. The training covered stall improvement, milking, feeding, and milk quality improvement. It has been seven years ago since the training was enforced in Subang. Hence, it can be identified the further problems of keeping dairy in Subang District, particularly on how far the application of the dairy training is implemented. Food Agriculture Organization was launched a model to evaluate keeping dairy, Good Dairy Farming Practice (GDFP) model (FAO/IDF 2011). There are 6 aspects in this model, those are animal health, hygiene milking, nutrition, animal welfare, environment, and social economic management. In this research, there are seven aspects that are used to evaluate dairy farming in Subang, six aspects of GDFP and reproduction aspect.

\section{MATERIAL AND METHODS}

\section{Object}

The object of the research was dairy farming practice while the subjects were dairy smallholder producers.

\section{Location sample}

Locations chosen as samples were Ciater and Sagalaherang Subdistrict, Subang District. The election of location was based on purposive sampling because both of them were the target of Danone's training and dominate the number of dairy farmers in the district $(81.44 \%)$.

\section{Data and respondentscollection}

The analysis is based on data available from a survey, held in November 2015, with personal interviews on a sample of 60 dairy farmers or $28 \%$ of total farmers in two location, Ciater and Sagalaherang Subdistrict, Subang District. The selection of farmers is based on Paturochman (2012) if number of population $(\mathrm{N})$ is between 200-500, the percentage of sample (n) is around $10-20 \%$. Respondents were collected by simple random sampling.

\section{Analysis method}

The analysis used GDFP method plus reproduction aspect to evaluate the dairy farm management. The determination of priority aspects used analytical hierarchy process (AHP). First step is problem arrangement hierarchy (in this research, there are seven aspects to be considered), then criteria and alternative determination which is valued by 1 5 scale, after that is determination of priority through pairwise comparisons method that used to determine priority of aspects through degree of matrix, then matrix is normalized. Step four is a logical consistency where the pairwise comparison has to have ordinal and cardinal relationship. Last step is determination of pairwise comparison value from criteria and alternative if the research involves participants.

To determine categories of GDFP, it was used qualitative categories out of quantitative value (Ditjennak 1983). There are four categories, 0.00-0.50 (worst), 0.511.00 (bad), 1.01-2.00 (not good enough), 2.01-3.00 (good enough) and 3.01-4.00 (good). 


\section{RESULTS AND DISCUSSION}

\section{Identification of respondents}

According to survey, the identification of respondents can divided into four parts, age of respondents, education, livelihood, and land ownership. The average age of respondent who keep dairy is between 15-55 years or it can be called in production ages (Table 1). The level of education of respondents is dominated by not graduated elementary to elementary, approximately $75-87 \%$. It means that most of them are not progressive people to adopt innovation and education factor influences a mind thinking (Muzzafak 2013). Almost all respondents said that their dairy farm as their livelihood in which the activity has been an important income source for their families. On the other side, only some respondents owna land more than one hectare but most of them own less than $5,000 \mathrm{~m}^{2}$. Land and dairy cattle are important assets for smallholder producers. If they lose one of the asset, they will be in vulnerable situation.

Table 2. Identification of respondents

\begin{tabular}{lcc}
\hline \hline \multirow{2}{*}{ Identification } & \multicolumn{2}{c}{ Locations } \\
\cline { 2 - 3 } & Ciater & Sagalaherang \\
\hline Age (years) & 0 & 0 \\
$<15$ & 17 & 27 \\
$15-55$ & 13 & 3 \\
$>55$ & & \\
Education & - & - \\
Illiterate & 10 & 6 \\
Elementary (no graduate) & 16 & 17 \\
Elementary & 3 & 1 \\
Junior High School & 1 & \\
Senior High School & & 29 \\
Livelihood & 30 & 1 \\
Dairy farmer & - & - \\
Rice farmer & - & \\
Others & & - \\
Land ownership & 2 & 5 \\
$>1$ hectare & 2 & 25 \\
$5000 \mathrm{~m}^{2}-1$ hectare & 26 & \\
$<5000 \mathrm{~m}^{2}$ & & \\
\hline
\end{tabular}

\section{Implementation good dairy farming practice}

Based on survey, it can be determined the implementation of GDFP aspects. Reproduction management is an important aspect in keeping dairy because milk production depends on reproduction activities. Analysis results on reproduction aspect on both of two study areas are 3.26 and 3.28 (Figure 1). All sub-aspects shows a good valued, except service per conception (S/C). Both of areas has a good knowledge on Fries Holland as a good breed. This result is similar to Simamora et al. (2015) that farmers in Kabupaten Karochosed the breed due to its productivity. Meanwhile, there is a problem with S/C sub- 
aspect where the value is the lowest. The average of S/C that respondents said was two times until cows pregnant. Service per conception is normal relatively among 1,6-2 (Rahmadhanil et al. 2015).

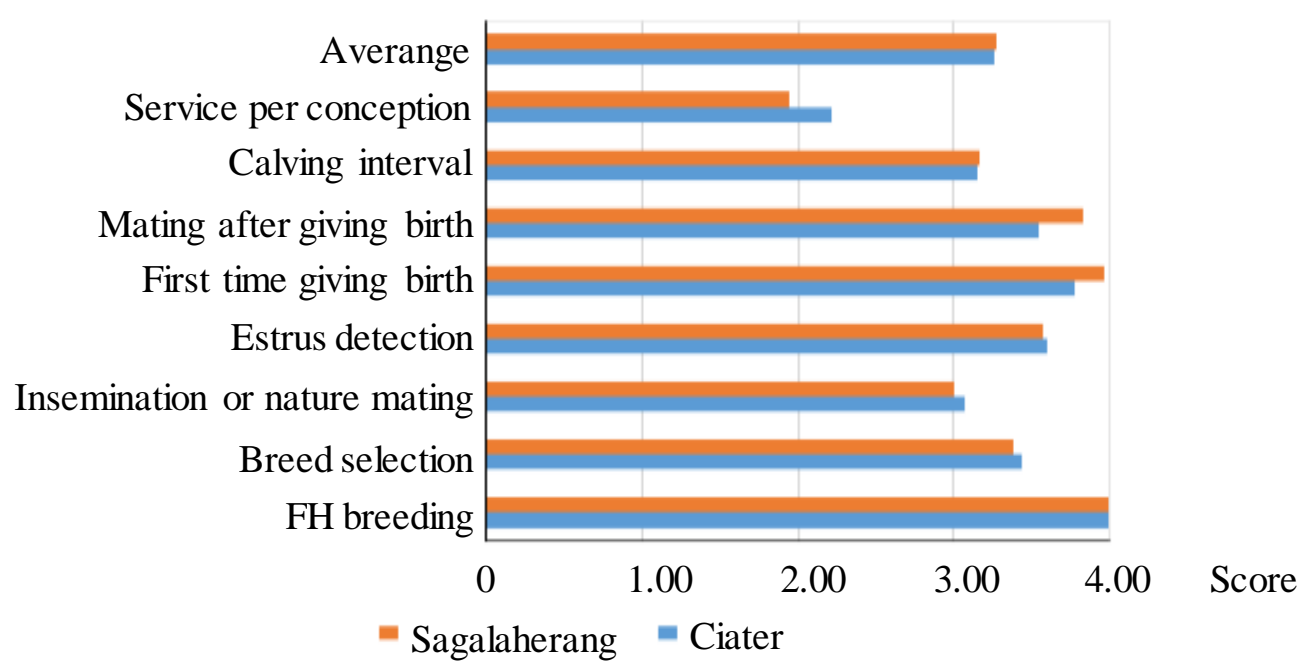

Figure 1. Reproduction aspect

Table 2. Animal health aspect

\begin{tabular}{lcc}
\hline \hline Animal health sub-aspects & Ciater & Sagalaherang \\
\hline Capacity of adaptation & 3.13 & 3.11 \\
Determination no. of cows & 2.63 & 2.37 \\
Vaccination & 3.08 & 3.11 \\
Considering buying cows/calves & 3.33 & 3.32 \\
Buying cows fever cause of price cheaper & 3.79 & 2.09 \\
Sharing diseases information & 2.07 & 2.09 \\
Stall hygiene from outsider & 2.77 & 2.63 \\
Handling disease in farm & 2.15 & 2.05 \\
Farm equipment & 3.45 & 3.26 \\
Permanent system identification & 2.21 & 2.25 \\
Animal health program in farm & 2.16 & 2.19 \\
Knowledge of disease signs & 3.89 & 3.78 \\
Curing cow fever & 2.21 & 2.35 \\
Isolation stall & 2.68 & 2.37 \\
Separation of milk contamination & 2.37 & 2.35 \\
Recording of cow fever treatment & 3.05 & 3.46 \\
Veterinary zoonosis management & 2.50 & 2.50 \\
Using legal drugs & 3.12 & 2.99 \\
How to use the drugs & 2.70 & 2.89 \\
How to give the drugs & 2.66 & 2.68 \\
How to keep and through after curing & 2.70 & 2.85 \\
\hline Average & 2.79 & 2.70 \\
\hline
\end{tabular}

Second aspect of GDFP is animal health. Cows will give positive respond if they are health. Protection and first handling disease in the farm are a pivotal point to keep dairy. 
According to survey, results indicates that value of animal health aspect reaches 2.79 and 2.70 (Table 2). It means that handling disease is not entirely implemented, the farmers only do simple things such as monitoring and controlling their cows. Apart from that, for instants, drug usage, curing disease, or something that could not be handled are the case ofanimal doctor or health medicine services from cooperative (KPSBU).

Milking will influence to quantity and quality of fresh milk. Therefore, the implementation of milking technique will help farmers to get a good result. Based on the data survey, it could be explained that the value of this aspect reached 3.49 and 3.45 (Table 3). It means that smallholder producers have implemented the standard operational procedure in milking. The majority of farmers use full hand method because of the easy one. One thing that they could not be implemented in the farm is wearing milking cloth. They do not have a special cloth for milking.

Table 3. Hygiene milking aspects

\begin{tabular}{lcc}
\hline \hline Hygiene milking sub-aspects & Ciater & Sagalaherang \\
\hline Checking cow before milking & 3.28 & 3.16 \\
Cleaning udder by warm water & 3.33 & 3.24 \\
Milking technique & 3.90 & 3.90 \\
Isolation cow fever from others & 3.28 & 3.16 \\
Renew equipment & 3.10 & 3.30 \\
Water scarcity & 2.20 & 3.08 \\
Drainage and ventilation in farm & 3.87 & 3.64 \\
Milking area hygiene & 3.90 & 3.90 \\
Wearing clean cloth when milking & 2.62 & 2.68 \\
Cleaning milking equipment & 3.90 & 3.90 \\
Milk collection area & 3.95 & 3.80 \\
Aluminum or stainless steel milkcan & 3.33 & 3.32 \\
Milk distribution directly to milk collection area & 3.95 & 3.80 \\
Cleaning milkcan using detergent or warm water & 3.95 & 3.32 \\
Accessibility to milk collection area & 3.74 & 3.52 \\
\hline Average & 3.49 & 3.45 \\
\hline
\end{tabular}

Next aspect is nutrition aspect. Nutrition influences dairy to produce fresh milk. Lack nutrition, such as grass and concentrate, will give a negative respond to reduce milk productivity. In general, the big problem in keeping dairy in Indonesia is lack feeding, especially grass in dry season. Farmers must find grass away from their home. Sometimes, they must compete with other farmers to cut and carry grass. Therefore, the value of nutrition aspect only reached 2.68 and 2.75 (Figure 2).

Recently, animal welfare has been top issue in global farming. This issue emerges accompany with animal right. Therefore, FAO puts this aspect being one of GDFP aspect. The value of this aspect was 3.12 and 3.04 in both areas (Figure 3). Farmers have a good knowledge to eliminate hunger and thirsty on their cows. Then, they tried to make cows comfortable in stall. The majority of farmers use carpet on stall floor because they argument that cows will give a good respond if the cows are given good services. In Figure 3 , it could be seen that freedom to behave normally is the lowest value in animal welfare aspect. Most of farmers do not release their cows because of less land for exercise. 


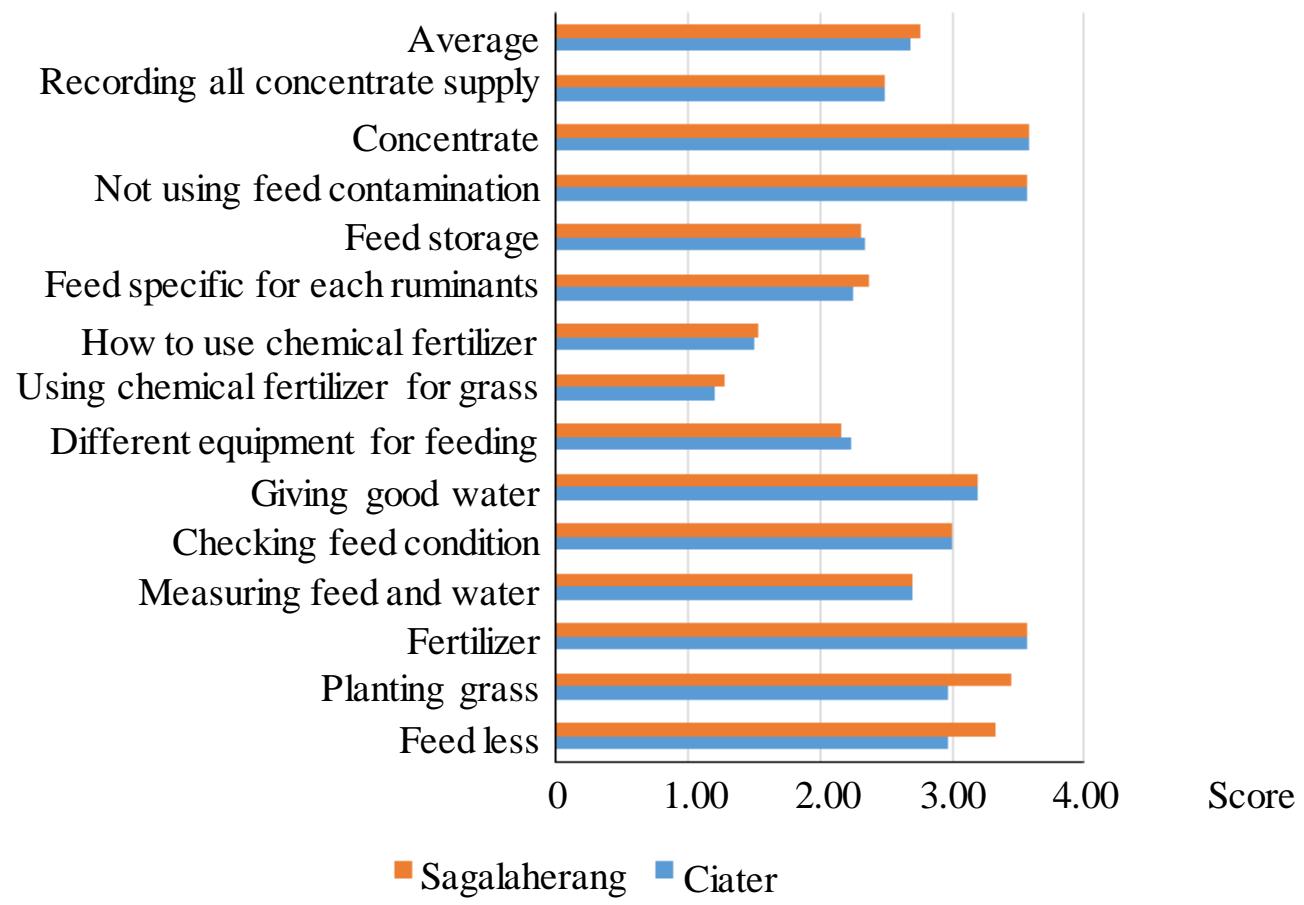

Figure 2. Nutrition aspect

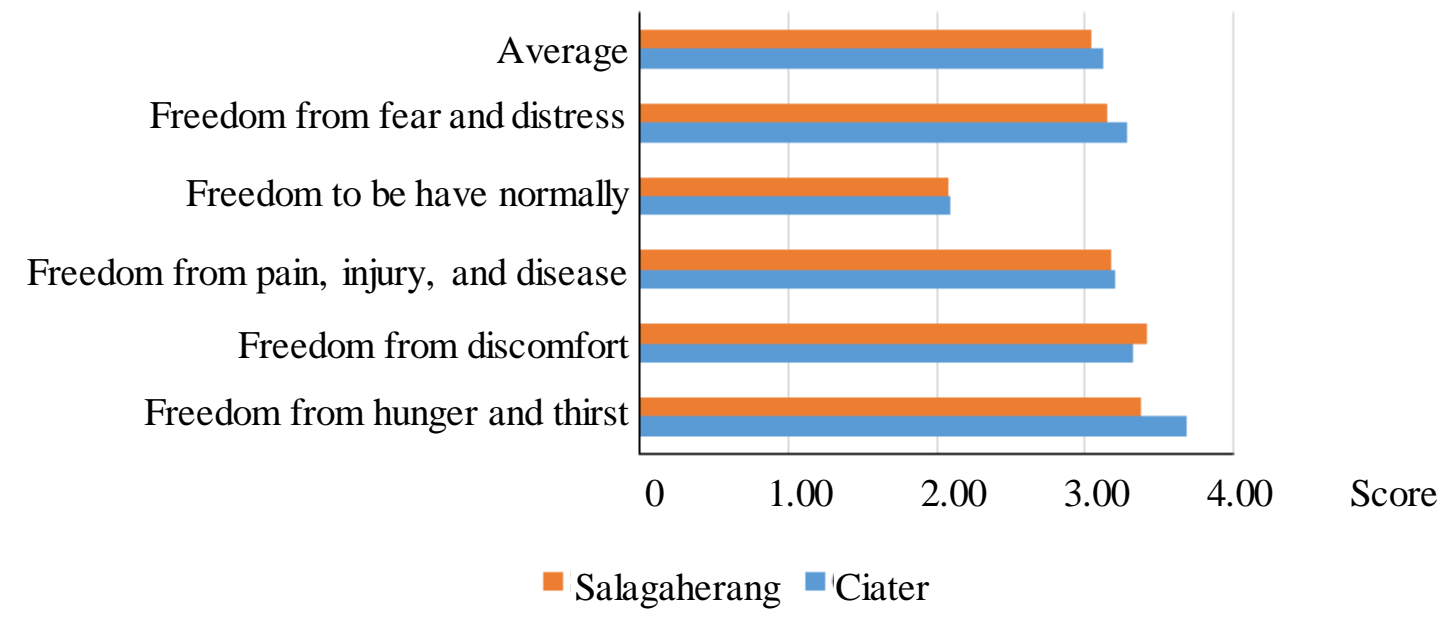

Figure 3. Animal welfare aspect

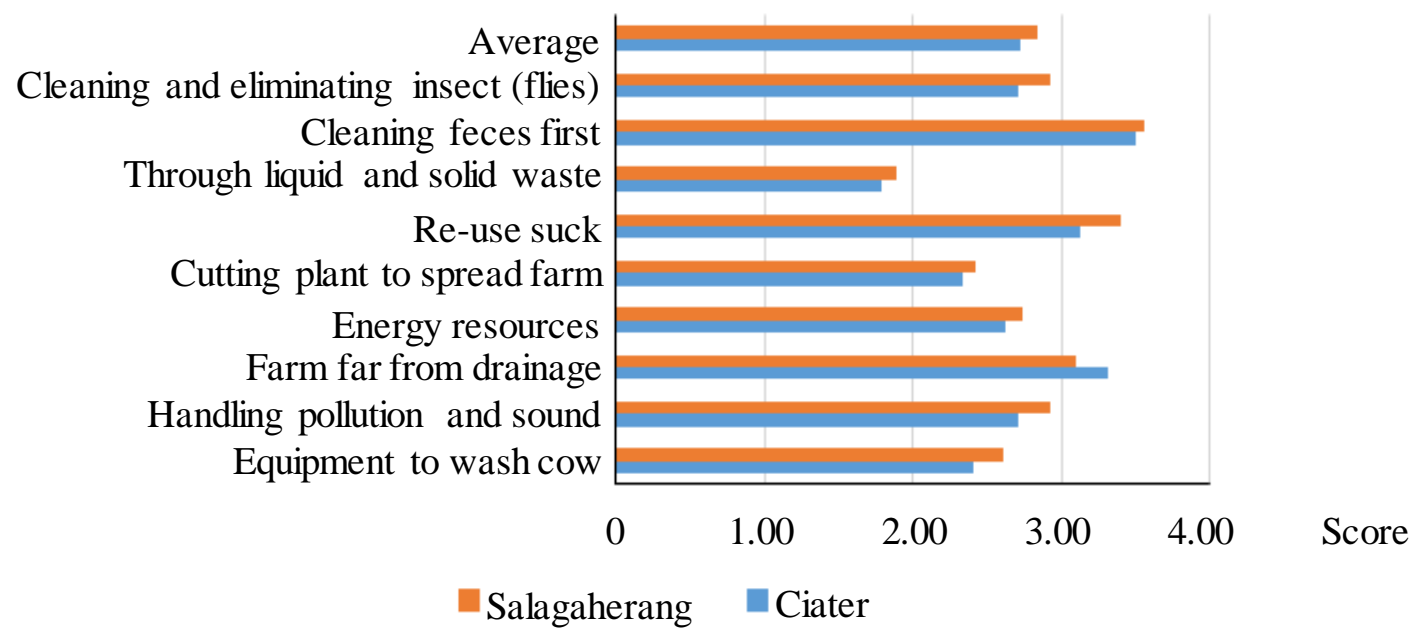

Figure 4. Environment aspect 
Last but not least, a good environment will give a good effect not only milk quality but also animal health. Furthermore, environment has become a central issue in global warming. FAO (2010) indicated that emission gas $\left(\mathrm{CO}_{2}, \mathrm{CH}_{4}\right.$, and $\left.\mathrm{N}_{2} \mathrm{O}\right)$ from farm to milk transportation $2.7 \%$ of total emission. Analysis result in the areas research determined that the value of environment aspect was lower than all aspects above. It shows that the environment has been not focused by farmers in Ciater and Sagalaherang, yet where as environment is very important to make a farm existence. Many cases of farm animal closed because they did not pay attention on environment.

Last, social and economic have a strong relationship with sustainability of farm because this aspect gives household income and their livelihood. It is not different from other farmers in other areas, family farm dominates dairy farming in Ciater and Sagalaherang. Unfortunately, the value of social and economic management aspect is the same as environment aspect. The value was 2.73 and 2.77 (Figure 5). It means that farmers could have a capacity to manage their farms well, yet.

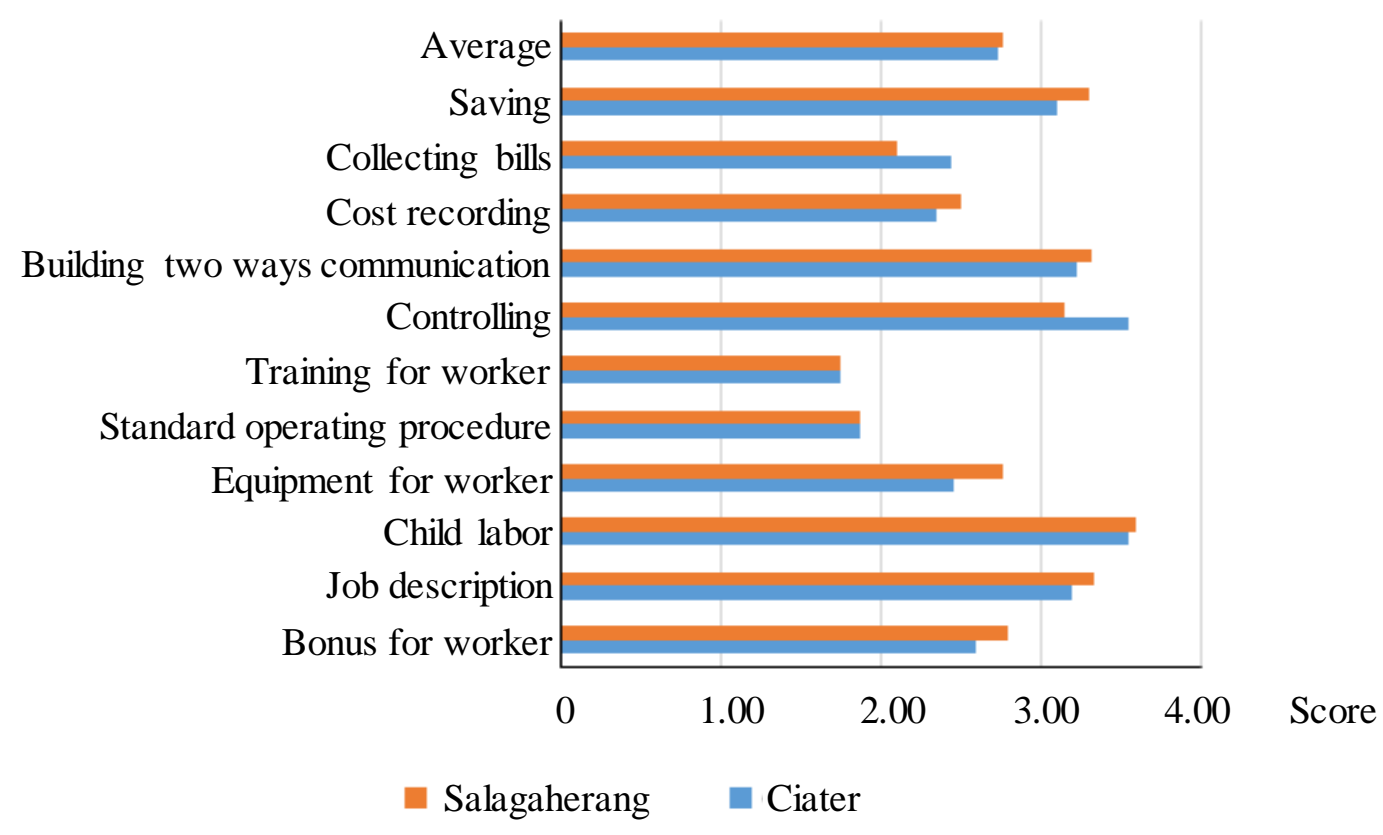

Figure 5. Social economic management aspect

\section{Is social economic the first priority?}

All aspects above can be united into one table to see what kind of aspects being a priority of farmers. The Table 4 shows that respondents in Ciater and Sagalaherang are good at milk hygiene, reproduction knowledge, and animal welfare. These aspects showed that their daily activities are being institutionalized. The other side, social economic management is in good enough category which the aspect has the same as category with animal health, nutrition, and environment. Lestari et.al (2015) showed respectively the priority of GDFP are reproduction aspect, and followed by milking hygiene, animal health, nutrition (feed and water), animal welfare, environment, and socio economic management. This research was held in South Bandung Farmer Cooperative (KPBS), Pangalengan.

Therefore, intervention program on dairy farming should be focused on four aspects of GDFP in Subang District. Simple training for those aspects can be given to increase their skills and capacities. They need to practice knowledge on how to handle cows fever for prevention. In the nutrition aspect, farmers need a simple technology to preserve grass to anticipate dry season. Feces is a big problem in those areas because it's only put in the 
backyard of their farms. Therefore, respondents need a technology to reuse and recycle the feces. Last, farmers need to manage their incomes and expenses because they always mix the financial between farm business and household expenses. Therefore, financial management training is important to train.

Table 4. Score and category of GDFP in Ciater and Sagalaherang

\begin{tabular}{lcccccc}
\hline \hline \multirow{2}{*}{ Good dairy farming practice } & \multicolumn{2}{c}{ Ciater } & & \multicolumn{2}{c}{ Sagalaherang } \\
\cline { 2 - 3 } \cline { 6 - 6 } & Value & Category & & Value & Category \\
\hline Reproduction & 3.26 & Good & & 3.28 & Good \\
Animal health & 2.79 & Good enough & & 2.70 & Good enough \\
Milking hygiene & 3.49 & Good & & 3.45 & Good \\
Nutrition & 2.68 & Good enough & & 2.75 & Good enough \\
Animal welfare & 3.12 & Good & & 3.04 & Good \\
Environment & 2.63 & Good enough & & 2.75 & Good enough \\
Social economic management & 2.73 & Good enough & & 2.77 & Good enough \\
\hline
\end{tabular}

\section{CONCLUSION}

To sum up the evaluation of GDFP implementation, there are two things that are being attention to develop dairy farming in Subang, those are:Milking hygiene gets the highest value of GDFP, followed by reproduction, and animal welfare. Surprisingly, social economic management aspect is not a priority in dairy farmers. The aspect have a similar value with animal health, nutrition, and evironment aspects. Therefore, intervention programs that should be trained in Subang District are focused on four aspects, animal health, nutrition, evironment, and social economic management.

\section{REFERENCES}

FAO/IDF. 2011. Guide to good dairy farming practice. Animal production and health guidelines. No. 8. Rome (Italy): Food and Agriculture Organization and International Dairy Federation.

Ditjennak. 1983. Laporan penerapan dampak uji coba dan faktor-faktor perencanaan di dalam penyuluhan peternakan. Jakarta (Indonesia): Direktorat Jenderal Peternakan.

FAO. 2010. Greenhouse gas emissions from the dairy sector: A life cycle assesment. Rome (Italy): FAO. http://www.fao.org/docrep/012/k7930e/k7930e00.pdf

Lestari NF, Makin M, Firman A. 2015. Hubungan antara good dairy farming practice dan income over feed cost pada peternakan sapi perah di koperasi peternak Bandung Selatan (KPBS) Pangalengan. Sumedang (Indonesia): Universitas Padjadjaran.

Dinas Peternakan Subang. 2014. Laporan tahunan Dinas Peternakan Kabupaten Subang Tahun 2014. Subang (Indonesia): Dinas Peternakan Kabupaten Subang.

Muzzafak. 2013. Pengaruh pendidikan dan tingkat ekonomi terhadap keputusan orang tua untuk menikah anak-anak mereka di Desa Karang Duwak, Kecamatan Arosbaya, Kabupaten Bangkalan. J Paradigma. 1.

Paturochman, M. 2012. Penentuan jumlah sampel dan teknik sampling untuk penelitian sosial dan ekonomi. Subang (Indonesia): Universitas Padjadjaran Press. 
Rahmadhanil PR, Mahdi H, Siswanto. 2015. Service per conception pada sapi perah laktasi di Balai Besar Pembibitan Ternak Unggulan dan Hijauan Pakan Ternak (BBPTU-HPT) Baturraden, Purwokerto, Jawa Tengah. J Integrated Livest Sci. 3:29-37.

Simamora T, Fuah AM, Atabany A, Burhanuddin. 2015. Evaluasi aspek teknis pada peternakan sapi perah di Kabupaten Karo Sumatera Utara. J Prod Sci Livest Tech. 3:52-58. 